\title{
Chemical composition of virgin olive oils from the Chemlali cultivar with regard to the method of the olive tree propagation
}

\author{
By M. Guerfel ${ }^{1, *}$, M.B. Mansour ${ }^{1}$, Y. Ouni ${ }^{2}$, F. Guido ${ }^{3}$, D. Boujnah ${ }^{4}$ and M. Zarrouk ${ }^{2}$ \\ ${ }^{1}$ Institut Supérieur de Biologie Appliquée de Medenine, Université de Gabes, B.P 522, 4100 Medenine, Tunisia \\ ${ }^{2}$ Centre de Biotechnologie de Borj Cédria, B.P. 901, 2050 Hammam-Lif, Tunisia \\ ${ }^{3}$ Dipartimento di Scienze Farmaceutiche, sede di Chimica Bioorganica e Biofarmacia, \\ via Bonanno 33, 56126 Pisa, Italy \\ ${ }^{4}$ Institut de l'Olivier, Station de Sousse, Rue Ibn Khaldoun, B.P. 14, 4061 Sousse,Tunisia \\ *Corresponding author: Guerfel_mk@yahoo.fr
}

\section{RESUMEN}

Composición química de aceites de oliva virgen de la variedad Chamlali en relación con el método de propagación del olivo.

En este trabajo se presenta por primera vez un estudio de discriminación basado en compuestos antioxidantes, estabilidad oxidativa y compuestos volátiles de muestras de aceites de oliva virgen obtenidos de frutos de la principal variedad de aceitunas tunecinas (Chemlali) a partir de dos métodos de propagación del olivo (chupones y estaquillas herbáceas). Se han encontrado diferencias significativas entre los aceites obtenidos por los dos métodos. Las muestras de aceites de oliva obtenidas de frutos de árboles de chupones tenían una mayor proporción de ácido oleico $(63,8 \%)$, un mayor contenido de clorofila y de carotenoides $(3,01 \mathrm{mg} / \mathrm{kg}$ y $1,9 \mathrm{mg} / \mathrm{kg}$, respectivamente), un mayor contenido de (E)-2 hexenal $(66,1 \%)$ y un mayor contenido en fenoles totales $(890 \mathrm{mg} / \mathrm{kg})$. Curiosamente, el aceite más estable se ha obtenido de las aceitunas de árboles de chupones, en comparación con las aceitunas de árboles de estaquillas herbáceas. Estos resultados pueden ser utilizados para discriminar y caracterizar los aceites de oliva Chamlali según el origen del olivo.

PALABRAS CLAVE: Ácidos grasos - Estaquilla herbácea - Estabilidad oxidativa - Chupones - Aceites de oliva virgen - Compuestos volátiles.

\section{SUMMARY}

Chemical composition of virgin olive oils from the Chemlali cultivar with regard to the method of the olive tree propagation.

This paper reports for the first time a discrimination study based on the antioxidant compounds, oxidative stability and volatile compounds of virgin olive oil samples obtained from fruits of the main Tunisian olive cultivar (Chemlali) using two methods of olive tree propagation (suckers and cuttings). There were significant differences between the oils from the two methods. Olive oil samples obtained from the fruits of trees from suckers had a higher content of oleic acid (63.8\%), higher contents of chlorophyll and carotenoids $(3.01 \mathrm{mg} / \mathrm{kg}$ and $1.9 \mathrm{mg} / \mathrm{kg}$ respectively), a higher content of $(E)-2$ hexenal $(66.1 \%)$ and a higher content in total phenols $(890 \mathrm{mg} / \mathrm{kg})$. Interestingly, more stable oil was obtained from the olives from suckers compared to the olives from cuttings. These results can be used to discriminate and to characterize the Chemlali olive oils from each origin of olive tree.

KEY-WORDS: Cuttings - Fatty acids - Oxidative stability - Suckers - Virgin olive oils - Volatile compounds.

\section{INTRODUCTION}

The chemical composition of virgin olive oil (VOO) depends on many factors: olive tree cultivation, harvesting, pedoclimatic conditions, olive cultivar, plant density and number of processing steps required; mainly crushing, malaxation and centrifugation (Salvador et al., 2003; Cerretani et al., 2005; Torres and Maestri, 2006; Guerfel et al., 2010).

Tunisia is a very important country in the olive oil producing world, the largest African exporter and fourth worldwide after Spain, Italy and Greece. The olive tree (Olea europaea L.) is present in practically every region of the country, up to the border of the southern dessert. The conventional method of olive tree propagation in Tunisia is based on vegetative multiplication using cuttings, grafting, or suckers. These methods have been frequently used for the propagation of some highly valued cultivars, particularly the Chemlali cultivar. The Chemlali cultivar is ubiquitous in the Tunisian arable land and contributes to up to $80 \%$ of the national olive oil production. Chemlali olive oil is characterized by the relatively low levels of oleic acid (53-55\%) and high levels of palmitic and linoleic acids (Manaï et al., 2007). Recently, a major effort has been made to improve the quality of olive oil produced in Tunisia. Perhaps, production improvement can be made once the main drawbacks are known (cultivar type and/or the origin of olives used for oil extraction).

This is the first evaluation of the chemical composition of Chemlali virgin olive oils in relation to the method used for the olive tree propagation (cuttings, suckers). Because of the importance of this cultivar for Tunisian oil production, the aim of this work was to characterize virgin olive oils of 
Chemlali trees from cuttings and suckers based on the study of major (fatty acids) and minor compounds (phenols, chlorophylls, carotenoids and volatiles) as well as on the oxidative stability.

\section{MATERIALS AND METHODS}

\subsection{Oil Sample Extraction}

Olive oil samples were obtained from fruits of the main Tunisian olive cultivar, Chemlali, which were picked by hand at the same stage of maturity from three trees during the crop season 2009/2010 (October) in a 4 ha olive orchard located in the Souassi center of Tunisia $\left(35^{\circ}, 49^{\prime} \mathrm{N}, 10^{\circ}, 30^{\prime} \mathrm{E}\right)$. The olive trees were planted in 1988 and were subjected to an identical fertilization regime and to all common olive cultivation practices. The same laboratory mill was used to prepare the olive oil samples. Only healthy fruits, without any kind of infection or physical damage, were processed in triplicate from trees from cuttings and from suckers. After harvesting, fresh olives (1.5-2.0 kg) from each fruit sample were washed and the leaves were removed. They were then crushed with a hammer crusher, and the paste was mixed at $25^{\circ} \mathrm{C}$ for $30 \mathrm{~min}$, centrifuged without the addition of warm water (oil produced from each extraction was $200-250 \mathrm{~mL} / \mathrm{kg}$ ), transferred to dark glass bottles, and stored for one week in the dark at $4^{\circ} \mathrm{C}$ until analysis.

\subsection{Determination of Oil Quality Parameters}

Free acidity, expressed as percent of oleic acid (\%18:1); peroxide value, given as milliequivalents of active oxygen per kilogram of oil (meqO2/ $\mathrm{kg}$ ); and UV absorption characteristics $\left(\mathrm{K}_{232}\right.$ and $\left.\mathrm{K}_{270}\right)$ were determined according to the analytical methods described in the European Union Commission Regulations EEC/2568/91 and EEC/1429/92.

\subsection{Fatty Acid Composition}

The fatty acids were converted to fatty acid methyl esters before analysis by shaking a solution of $0.2 \mathrm{~g}$ oil and $3 \mathrm{~mL}$ of hexane with $0.4 \mathrm{~mL}$ of $2-\mathrm{N}$ methanolic potassium hydroxide, and analyzed using a Hewlett-Packard (HP 4890D; HewlettPackard Company, Wilmington, DE) chromatograph equipped with a capillary column (Supelcowax: $30 \mathrm{~m} \times 0.53 \mathrm{~mm} ; 0.25 \mathrm{~mm}$ ), a split/splitless injector and a flame ionization (FID) detector. The carrier gas was nitrogen at a flow rate of $1 \mathrm{~mL} / \mathrm{min}$. The temperatures of the injector, the detector and the oven were held at 220,250 and $210^{\circ} \mathrm{C}$, respectively. The injection volume was $1 \mu \mathrm{L}$.

\subsection{Pigment Content}

Chlorophyll and carotenoid contents were determined colorimetrically as previously described (Mínguez-Mosquera et al., 1991). The maximum absorption at $670 \mathrm{~nm}$ is related to the chlorophyll fraction, while the maximum absorption at $470 \mathrm{~nm}$ is related to the carotenoid fraction. The values of the coefficients of specific extinction applied were $\mathrm{E} 0=613$ for pheophytin, a major component in the chlorophyll fraction, and E0 $=2,000$ for lutein, a major component in the carotenoid fraction. Thus, the pigment contents were calculated as follows:

$$
\begin{aligned}
& \text { Chlorophyll }(\mathrm{mg} / \mathrm{kg})=\frac{\left(\mathrm{A}_{670} \times 10^{6}\right)}{(613 \times 100 \times \mathrm{d})} \\
& \text { Carotenoid }(\mathrm{mg} / \mathrm{kg})=\frac{\left(\mathrm{A}_{470} \times 10^{6}\right)}{(2,000 \times 100 \times \mathrm{d})}
\end{aligned}
$$

where $A$ is the absorbance and $d$ is the spectrophotometer cell thickness $(1 \mathrm{~cm})$.

\subsection{Total phenolic content}

Total phenol contents were quantified colorimetrically (Ranalli et al., 1999). Phenolic compounds were isolated by the triple extraction of a solution of oil $(10 \mathrm{~g})$ in hexane $(20 \mathrm{~mL})$ with $30 \mathrm{~mL}$ of a methanol and water mixture $(60: 40, \mathrm{v} / \mathrm{v})$. The Folin-Ciocalteau reagent (Merck Schuchardt OHG,Hohenbrunn, Germany) was added to a suitable aliquot of the combined extracts, and the absorption of the solution at $725 \mathrm{~nm}$ was measured. Values are given as milligrams of caffeic acid per kilogram of oil (Gutfinger, 1981).

\subsection{Volatile compound analyses}

Solid phase micro extraction was used as a technique for headspace sampling of virgin olive oils. SPME devices coated with polydimethylsiloxane (PDMS, $100 \mu \mathrm{m}$ ) were used to sample the headspace of $2 \mathrm{~mL}$ of olive oil inserted into a $5 \mathrm{~mL}$ glass septum vial and allowed to equilibrate for $30 \mathrm{~min}$. After the equilibration time, the fiber was exposed to the headspace for $50 \mathrm{~min}$ at room temperature $\left(25^{\circ} \mathrm{C}\right)$. Once sampling was finished, the fiber was withdrawn into a needle and transferred to the injection port of the GC-FID and GC-MS system. GC-EIMS separations were performed with a Varian CP 3800 gas chromatograph equipped with a DB-5 Capillary column $(30 \mathrm{~m} \times 0.25 \mathrm{~mm}$; coating thickness $=0.25 \mu \mathrm{m})$ and a Varian Saturn 2000 ion trap mass detector.

Analytical conditions were as follows: injector and transfer line temperature at 250 and $240^{\circ} \mathrm{C}$, respectively; oven temperature was programmed from 60 to $240^{\circ} \mathrm{C}$ at $3^{\circ} \mathrm{C} \mathrm{min}{ }^{-1}$; carrier gas, helium at $1 \mathrm{~mL} \mathrm{~min}{ }^{-1}$; splitless injection. Identification of the constituents was based on comparison of the retention times with those of authentic samples, comparing their linear retention indices relative to the series of $n$-hydrocarbons, and on computer matching against commercial (NIST 98 and ADAMS) and homemade library mass spectra built from pure substances and components of known oils and MS literature data (Jennings and Shibanoto1980; Davies, 1990; Adam, 1995). Moreover, the molecular weights of all the identification 
substances were confirmed by GC-CIMS, using $\mathrm{MeOH}$ as the $\mathrm{Cl}$ ionizing gas.

\subsection{Oil Stability}

Oxidative stability was evaluated by the Rancimat method (Gutiérrez, 1989). Stability was expressed as the oxidation induction time (h), measured with the Rancimat 743 apparatus (Metrohm, Herisau Switzerland), using an oil sample of $3.6 \mathrm{~g}$. The oil temperature was $101.6^{\circ} \mathrm{C}$ and the air flow was $10 \mathrm{~L} / \mathrm{h}$.

\subsection{Statistical Analysis}

Significant differences between means were determined by an analysis of variancewhich applied a Duncan's test. Differences were considered statistically significant when the probability was greater than $99 \%(P<0.01)$. The statistical analysis was performed using SPSS 13.0 for Windows (SPSS Inc., 2004).

\section{RESULTS}

\subsection{Fatty Acid Composition}

Compared to the olive oil samples obtained from cuttings, the olive oil samples obtained from suckers had a higher content of oleic acid $(63.8 \%)$ (Table 1). The palmitic acid content varied between $14.3 \%$ and $17.5 \%$. The olive oil samples also contained low amounts of linolenic acid (C18:3), arachidic acid (C20:0) and palmitoleic acid (C16:1). The olive oil samples obtained from trees cuttings were found to be rich in total saturated fatty acids $(21.1 \%)$, essentially due to their high content of palmitic acid. The olive oil samples obtained from suckers were found to show a higher content in total monounsaturated fatty acids (64\%), due to their high percentage of oleic acid. The olive oil samples obtained from trees from cuttings were found to have a higher percentage of polyunsaturated fatty acids $(20 \%)$ due to their high content in linoleic acid.

\subsection{Oil Quality Parameters and Pigment Contents}

The olives from both methods of propagation yielded extra virgin olive oils, but the profile of the analytical parameters (e.g., free fatty acid content, peroxide value and extinction coefficients at 232 and $270 \mathrm{~nm}$ ) showed some slight differences (Table 2). The oils from suckers had higher contents of chlorophyll and carotenoids.

\subsection{Changes in Oxidative Stability}

The olive oil samples obtained from the fruits of the trees from suckers were found to have higher contents in total phenols $(890 \mathrm{mg} / \mathrm{kg}$ ) (Table 2). Therefore, significant differences between the two propagation methods were observed with regard to the total phenol contents, with more stable oil being obtained from the trees from suckers (50.2 h).

\subsection{Volatile Compounds Analyses}

The aromatic composition of the different samples is reported in Table 3. Fifteen compounds have been characterized by GC-FID and GC-MS analysis. (E)-2-Hexenal was the major constituent, accounting for about $55 \%$ of all volatiles. Other compounds present in relatively high concentrations were hexenal $(2.7-4.8 \%),(E, Z)$ 2,4-heptadienal (9.2-11.9\%), (E)- $\beta$-ocimene (0.7-1), nonanal $(0.7 \%)$, and $(E, E)-\alpha$-farnesene $(0.6-2.1 \%)$. The chemical composition of the volatile fraction of Chemlali olive oils was quite variable,

Table 1

Fatty acid composition of virgin olive oil samples from the two ways of olive tree propagation

\begin{tabular}{lcc}
\hline & Olives from cuttings & Olives from suckers \\
\hline Palmitic acid C16 :0 & $14.32 \pm 0.11 \mathrm{a}$ & $17.51 \pm 0.12 \mathrm{~b}$ \\
Palmitoleic acid C16 :1 & $0.33 \pm 0.08 \mathrm{a}$ & $0.51 \pm 0.01 \mathrm{a}$ \\
Stearic acid C18 :0 & $2.96 \pm 0.16 \mathrm{a}$ & $3.20 \pm 0.15 \mathrm{a}$ \\
Oleic acid C18 :1 & $60.16 \pm 1.28 \mathrm{a}$ & $63.86 \pm 0.41 \mathrm{~b}$ \\
Linoleic acid C18 :2 & $19.84 \pm 0.69 \mathrm{~b}$ & $16.0 \pm 0.24 \mathrm{a}$ \\
Linolenic acid C18 :3 & $0.76 \pm 0.09 \mathrm{a}$ & $0.52 \pm 0.04 \mathrm{a}$ \\
Arachidic acid C20 :0 & $0.44 \pm 0.02 \mathrm{a}$ & $0.38 \pm 0.04 \mathrm{a}$ \\
Saturated fatty acids (SFAs) & $17.72 \pm 0.29 \mathrm{a}$ & $21.09 \pm 0.31 \mathrm{~b}$ \\
Monounsaturated fatty acids (MUFAs) & $60.49 \pm 1.36 \mathrm{a}$ & $64.37 \pm 0.42 \mathrm{~b}$ \\
Polyunsaturated fatty acids (PUFAs) & $20.60 \pm 0.78 \mathrm{~b}$ & $16.52 \pm 0.28 \mathrm{a}$ \\
\hline
\end{tabular}

${ }^{a, b}$ Mean \pm S.D. $(n=6)$. Significant differences within the same row are shown by different letters $(P<0.01)$. 
Table 2

Quality parameters of Chemlali olive oil Samples from the two ways of olive tree propagation

\begin{tabular}{lcc}
\hline & Olives from cuttings & Olives from suckers \\
\hline Acidity $(\% \mathrm{C} 18: 1)$ & $0.8 \pm 0.1 \mathrm{~b}$ & $0.64 \pm 0.03 \mathrm{a}$ \\
$\mathrm{PV}\left(\mathrm{Meq} \mathrm{O}_{2} / \mathrm{Kg}\right)$ & $17 \pm 1 \mathrm{~b}$ & $15 \pm 0.58 \mathrm{a}$ \\
$\mathrm{K}_{270}$ & $0.08 \pm 0.01 \mathrm{a}$ & $0.07 \pm 0.08 \mathrm{a}$ \\
$\mathrm{K}_{2} 32$ & $0.55 \pm 0.18 \mathrm{a}$ & $2.13 \pm 0.09 \mathrm{~b}$ \\
Oxidative stability $(\mathrm{h})$ & $46.7 \pm 2.30 \mathrm{a}$ & $50.2 \pm 1.80 \mathrm{~b}$ \\
Chlorophylls $(\mathrm{mg} / \mathrm{kg})$ & $2.18 \pm 0.25 \mathrm{a}$ & $3.01 \pm 0.15 \mathrm{~b}$ \\
Carotenoids $(\mathrm{mg} / \mathrm{kg})$ & $1.13 \pm 0.22 \mathrm{a}$ & $1.9 \pm 0.19 \mathrm{~b}$ \\
Phenols $(\mathrm{mg} / \mathrm{kg})$ & $730 \pm 13.5 \mathrm{a}$ & $890 \pm 9.5 \mathrm{~b}$ \\
\hline
\end{tabular}

${ }^{a, b}$ Mean \pm S.D. $(n=6)$. Significant differences within the same row are shown by different letters $(P<0.001)$. $\mathrm{PV}$, peroxide value; $\mathrm{K}_{232}$ and $\mathrm{K}_{270}$, values of specific extinction given as absorbance at 232 and $270 \mathrm{~nm}$, respectively.

Table 3

Composition of the volatile fraction obtained from Chemlali virgin olive oils extracted by HS-SPME

\begin{tabular}{lccc}
\hline & LRI & Olives from cuttings & Olives from suckers \\
\hline Hexanal & 800 & $4.8 \mathrm{~b}$ & $2.7 \mathrm{a}$ \\
$(E)$-2-hexenal & 851 & $59.8 \mathrm{a}$ & $66.1 \mathrm{~b}$ \\
1-hexanol & 871 & - & $5.5 \mathrm{a}$ \\
$(E, Z)-2,4$-heptadienal & 998 & $9.2 \mathrm{a}$ & $11.9 \mathrm{~b}$ \\
$(E)$ - $\beta$-ocimene & 1051 & $1 \mathrm{a}$ & $0.7 \mathrm{a}$ \\
nonanal & 1104 & $0.7 \mathrm{a}$ & $0.7 \mathrm{a}$ \\
Decanal & 1206 & $7.5 \mathrm{~b}$ & $4.9 \mathrm{a}$ \\
Tridecane & 1300 & $3.9 \mathrm{a}$ & - \\
$\alpha$-copaene & 1377 & $0.2 \mathrm{a}$ & - \\
Isocaryophyllene & 1407 & $1.1 \mathrm{a}$ & $0.5 \mathrm{a}$ \\
$\beta$-caryophyllene & 1418 & $2.5 \mathrm{~b}$ & $1.2 \mathrm{a}$ \\
dihydro-b-ionone & 1435 & $0.1 \mathrm{a}$ & - \\
$\alpha$-humulene & 1456 & $1.3 \mathrm{~b}$ & $0.7 \mathrm{a}$ \\
$(E, E)$ - $\alpha$-farnesene & 1505 & $2.1 \mathrm{~b}$ & $0.6 \mathrm{a}$ \\
Cedrol & 1597 & $0.7 \mathrm{a}$ & $0.2 \mathrm{a}$ \\
Total identified & & 94.9 & 95.7 \\
\hline
\end{tabular}

LRI: linear retention indices; Data values expressed in $\mathrm{mg} / \mathrm{kg} .{ }^{\mathrm{a}, \mathrm{b}}$ Mean \pm S.D. $(\mathrm{n}=3)$. Significant differences within the same row are shown by different letters $(P<0.005)$. - compound not detected.

depending on the method used for olive tree propagation. The volatile fraction of the oil from trees from cuttings was characterized by the pre-eminence of two compounds: $(E, Z)-2,4$ heptadienal (9.2\%) and $(E)-2$-hexenal (59.8\%). The other main compounds detected were decanal $(7.5 \%)$, hexanal $(4.8 \%)$, tridecane $(3.9 \%)$, $\beta$-caryophyllene (2.5\%), (E,E)- $\alpha$-farnesene $(2.1 \%)$, isocaryophyllene $(1.1 \%), \alpha$-humulene $(1.3 \%)$ and cedrol $(0.7 \%)$. The volatile fraction of the oil from suckers was characterized by the pre-eminence of two compounds: (E)-2-hexenal (66.1\%) and $(E, Z)-2,4$-heptadienal $(11.9 \%)$ which may be used as markers to differentiate the VOO obtained from the two methods of olive tree propagation. The other main compounds detected were 1-hexanol (5.5\%), decanal (4.9\%), hexanal (2.7\%), $\beta$-caryophyllene $(0.6 \%), \quad(Z)$-3-hexenyl acetate (4.5\%), cyclosativene (3.0\%), (E)-2-decenal (1.2\%), nonanal $(0.7 \%)$ and $\alpha$-humulene $(0.7 \%)$. Differences in the levels of esters in olive oil samples were not clearly observed between the methods adopted for olive tree propagation. Moreover, in the oils from the two methods of olive tree propagation differences were found in the content of $(E, E)-\alpha-$ farnesene. 


\section{DISCUSSION}

The fatty acid composition of Chemlali from trees from suckers and cuttings was characterized by relatively high levels of oleic and linoleic acids. These results are similar to those reported by several authors for other olive oil varieties cultivated in Tunisia (Ben Temime et al., 2006; Krichene et al., 2007). The differences in the method of olive tree propagation led to differences in the fatty acid composition of virgin olive oil. Morello et al. (2004) reported that several agronomic parameters could modify the fatty acid composition of olive oil. The most studied aspects include cultivar and origin, fruit ripening, harvest period, climatic conditions and soil characteristics. However, our results show that the origin of the tree had little influence on the analytical parameters (free fatty acid content, peroxide value and extinction coefficients at 232 and $270 \mathrm{~nm}$ ) (Table 2), which are affected by factors causing damage to the fruits (e.g. olive fly attacks or improper methods of harvesting, transport and storage of olives) (Kiritsakis et al., 1998). In addition, olive oil samples obtained from the fruits of trees from both propagation methods were found to have varied chlorophyll and carotenoids contents. The total pigment content in olive oil is an important parameter for evaluating olive oil quality. Furthermore, pigments are involved in auto-oxidation and photo-oxidation mechanisms (Gutiérrez, 1989).

Stability to oxidation is an important property of olive oil, which is improved by synergistic interactions between the various antioxidants present in the oil itself, and also depends on the lipid composition. Oxidative stability of the Chemlali olive oils varied according to the method adopted for olive tree propagation (Table 2). Moreover, the two studied olive oils presented a good correlation between total phenols $(r=0.80)$, and oxidative stability measured by Rancimat. A good direct correlation between oxidative stability and total phenolic content has been previously reported by other authors (Gutiérrez et al., 2001). Significant differences among the two propagation methods were observed with regard to the total phenol contents. Olive oil is the only vegetable oil which contains appreciable amounts of phenolic compounds (which were represented basically by o-diphenols) acting as antioxidant substances and conferring to it a greater stability against oxidation during storage (Bendini et al., 2007).

$(E)$-2-hexenal was the principal volatile identified in the oils from the two propagation methods. $(E)-2$ hexenal was also the main volatile reported among the constituents of olive oil aroma (Ben Temime et al., 2006; Vichi et al., 2003). From the levels of the esters in the olive oils samples it can be hypothesized that levels of alcohol acetyl transferase (AAT) are not dependent on the origin of the olive tree. However, some differences in the levels of some terpenes hydrocarbons were observed in our olive oils samples. The hydrocarbons of olive oil have been studied by different authors as possible markers to distinguish virgin olive oil from different olive varieties or geographical origins (Vichi et al., 2003; Aparicio and Luna, 2002; Bortolomeazzi et al., 2001; Guinda et al., 1996).

\section{CONCLUSION}

In conclusion, the olive oils samples from both methods of olive tree propagation were within the limits established in the European Regulation, allowing them to be classified as extra virgin olive oils. However, our results showed that olive oil quality was different when the olive tree is from suckers or from cuttings. The oils obtained from the fruits of trees from suckers and compared to oils from trees from cuttings showed high levels of antioxidants along with an increased oxidative stability and high level of oleic acid.

\section{REFERENCES}

Adams RP. 1995. Identification of essential oil components by gas chromatography-mass spectroscopy. Carol Stream, IL: Allured Publishing Company.

Aparicio R, Luna G. 2002. Characterisation of monovarietal virgin olive oils. Eur. J. Lipid Sci. Technol. 104, 614627

Ben Temime S, Campeol E, Cioni PL, Daoud D, Zarrouk M. 2006. Volatile compounds from Chétoui olive oil and variations induced by growing area. Food Chem. 99, 315-325

Bendini A, Cerretani L, Carrasco-Pancorbo A, GómezCaravaca AM, Segura- Carretero A, FernándezGutiérrez A, Lercker G. 2007. Phenolic molecules in virgin olive oils: a survey of their sensory properties, health effects, antioxidant activity and analytical methods. An overview of the last decade. Molecules, 12, 1679-1719.

Bortolomeazzi R, Berno P, Pizzale L, Conte LS. 2001. Sesquiterpene, alkene, and alkane hydrocarbons in virgin Olive oils of different varieties and geographical origins. J. Agric. Food Chem. 49, 3278-3283.

Cerretani L, Bendini A, Rotondi A, Lercker G, GallinaToschi T. 2005. Analytical comparison of monovarietal virgin olive oils obtained by both a continuous industrial plant and a low-scale mill. Eur. J. Lipid Sci. Technol. 107, 93-100.

Davies NW. 1990. Gas chromatographic retention indexes of monoterpenes and sesquiterpenes on methyl silicone and carbowax $20 \mathrm{M}$ phases. J. Chrom. 503, 1-24.

EEC. 1991. Characteristics of olive oil and olive pomace and their analytical methods. Regulation EEC/2568/91 and latter modifications. Off. J. Eur. Communities 248, 1-82.

EEC. 1992. European Union Commission. Regulation EEC/1429/92 amending Regulation EEC2568/91 on the characteristics of olive oil and olive residue oil and on the relevant methods of analysis. Off. J. Eur. Communities, 150, 17-20.

Guerfel M, Zaghdoud C, Jebahi K, Boujnah D, Zarrouk M. 2010. Effects of the planting density on virgin olive oil quality of "Chemlali" olive trees (Olea europaea L.). J. Agric. Food Chem. 58, 12469-12472. 
Guinda A, Lanzón A, Albi T. 1996. Differences in hydrocarbons of virgin olive oils obtained from several olive varieties. J. Agric. Food Chem. 44, 1723-1726.

Gutfinger T. 1981. Polyphenols in olive oils. J. Am. Oil Chem. Soc. 58, 966-968.

Gutiérrez F, Arnaud T, Garrido A. 2001. Contribution of polyphenols to the oxidative stability of virgin olive oil. J. Sci. Food Agric. 81, 1-8.

Gutiérrez F. 1989. Determination of theoxidative stability of virgin olive oils. Comparison between AOM and Rancimat methods). Grasas Aceites, 40, 1-4.

Jennings W, Shibanoto T. 1980. Qualitative analysis of flavor and fragrance volatiles by glass capillary chromatography. New York: Academic Press.

Kiritsakis AK, Nauos GD, Polymenoupoulos Z, Thomai T, Sfakiotakis EY. 1998. Effect of fruit storage conditions on olive oil quality. J Am. Oil Chem. Soc. 75, $721-724$.

Krichene D, Taamalli W, Daoud D, Salvador MD, Fregapane G, Zarrouk M. 2007. Phenolic compounds, tocopherols and other minor components in virgin olive oils of some Tunisian varieties. J Food Biochem, 31, 179-194.

Manaï H, Haddada FM, Trigui A, Daoud D, Zarrouk M. 2007. Compositional quality of virgin olive oil from two new Tunisian cultivars obtained through controlled crossing. J. Sci. Food Agric. 87, 600-606.
Mínguez-Mosquera MI, Rejano-Navarro L, Gandulrojas B, Sánchez-Gómez AH, Garrido-Fernández J. 1991. Color pigment correlation in virgin olive oil. J. Am. Oil Chem. Soc. 86, 332-336.

Morello JR, Motilva MJ, Tovar MJ, Romero MP. 2004. Changes in commercial virgin olive oil (cv. Arbequina) during storage, with special emphasis on the phenolic fraction. Food Chem. 85, 357-364.

Ranalli A, De Mattia G, Patumi M, Proietti P. 1999. Quality of virgin olive oil as influenced by origin area. Grasas Aceites, 50, 249-259.

Salvador MD, Aranda F, Gòmez-Alonso S, Fregapane G. 2003. Influence of extraction system, production year and area on Cornicabra virgin olive oil: a study of five crop seasons. Food Chem. 80, 359-366.

Torres MM, Maestri DM. 2006. Chemical composition of Arbequina virgin olive oil in relation to extraction and storage conditions. J. Sci. Food Agric. 2006, 86, 2311-2317.

Vichi S, Pizzale L, Conte LS, Buxaderas S, LópezTamames E. 2003. Solidphase microextraction in the analysis of virgin olive oil volatiles fraction: Characterisation of virgin olive oils from two distinct geographical areas of northern Italy. J Agric Food Chem. 57, 6572-6577.

Recibido: $10 / 1 / 12$ Aceptado: $30 / 3 / 12$ 